\title{
Neospora caninum and/or Toxoplasma gondii Seroprevalence: Vaccination against PCV2 and Muscle Enzyme Activity in Seropositive and Seronegative Pigs
}

\author{
Labrini V. Athanasiou ${ }^{1, *(\mathbb{D})}$, Vasileios G. Papatsiros ${ }^{1} \mathbb{D}$, Victoria M. Spanou ${ }^{1}$ (D), Eleni G. Katsogiannou ${ }^{1}(\mathbb{D})$ and \\ Anna Dedousi ${ }^{2}$ (D) \\ 1 Department of Medicine, Faculty of Veterinary Medicine, University of Thessaly, 43100 Karditsa, Greece \\ vpapatsiros@vet.uth.gr (V.G.P.); vispanou@uth.gr (V.M.S.); elkatsog@uth.gr (E.G.K.) \\ 2 Veterinary Research Institute, HAO-Demeter, 57001 Thessaloniki, Greece; dedousi@vri.gr \\ * Correspondence: lathan@vet.uth.gr; Tel.: +30-2441-066-009; Fax: +30-2441-066-053
}

Citation: Athanasiou, L.V.; Papatsiros, V.G.; Spanou, V.M.; Katsogiannou, E.G.; Dedousi, A. Neospora caninum and/or Toxoplasma gondii Seroprevalence: Vaccination against PCV2 and Muscle Enzyme Activity in Seropositive and Seronegative Pigs. Microorganisms 2021, 9, 1097. https://doi.org/ 10.3390/microorganisms 9051097

Academic Editors: Gereon R M. Schares and Paweł Stefanoff

Received: 21 March 2021

Accepted: 18 May 2021

Published: 20 May 2021

Publisher's Note: MDPI stays neutral with regard to jurisdictional claims in published maps and institutional affiliations.

Copyright: (C) 2021 by the authors. Licensee MDPI, Basel, Switzerland. This article is an open access article distributed under the terms and conditions of the Creative Commons Attribution (CC BY) license (https:// creativecommons.org/licenses/by/ $4.0 /)$.

\begin{abstract}
Neospora caninum and Toxoplasma gondii affect both humans and animals worldwide. To investigate their seroprevalence and differences in seropositivity between pigs vaccinated and unvaccinated against porcine circovirus 2 (PCV2), as well as differences in muscle enzyme activity between seropositive and seronegative pigs, blood samples were collected from 380 sows. Antibodies against T. gondii and N. caninum were detected by an indirect immunofluorescence antibody (IFA) assay, while the activities of creatine kinase (CK) and aspartate aminotransferase (AST) were biochemically assessed. Out of the 364 sows finally included in the study, $4.4 \%, 3.5 \%$, and $0.5 \%$ were seropositive to T. gondii, N. caninum, or both. A significantly higher percentage of seropositivity against $T$. gondii and/or N. caninum in PCV2 unvaccinated pigs compared with vaccinated pigs was observed. Increased serum activities of CK and AST were detected in $71.43 \%$ and $100 \%$ of only against T. gondii $(\mathrm{T}+)$ and $63.64 \%$ and $90.91 \%$ of only against $N$. caninum $(\mathrm{N}+)$ seropositive sows, respectively, and were significantly higher compared to seronegative animals. T. gondii and N. caninum seropositivity, especially in presumed immunocompromised pigs, and the evidence of muscle damage highlight their importance as a zoonotic pathogen and animal model of human infection, respectively.
\end{abstract}

Keywords: aspartate aminotransferase; creatine kinase; immunosuppression; Neospora caninum; PCV2; pigs; serology; Toxoplasma gondii; vaccination

\section{Introduction}

Protozoan parasites of the phylum Apicomplexa infect several animal species, while some of them are of zoonotic importance. Toxoplasma gondii and Neospora caninum are closely related intracellular protozoan parasites belonging to the Coccidia subclass [1]. Tissue cyst formation and transmission via environmentally shed sporulated oocysts are some of their shared biological features [2,3]. Both organisms follow an indirect transmission cycle with carnivores being the definitive hosts and a broad spectrum of mammalian species, including humans and birds, serving as intermediate hosts. The main routes of infection in both humans and animals is by the ingestion of coccidian oocysts spread in the environment by infected carnivores' feces or after consumption of encysted bradyzoites of the intermediate hosts' tissues [3].

T. gondii is zoonotic, infecting $30-50 \%$ of the world's human population [4]. Over 1 million cases of toxoplasmosis are estimated every year in Europe [5]. N. caninum is unlikely to cause disease in immunocompetent individuals. However, although the presence of the parasite as well as antibodies against $N$. caninum have been reported in humans [6], the zoonotic potential of neosporosis needs further elucidation. Research on the prevalence and epidemiology of T. gondii among different countries and animal species is critical for the development of prevention strategies for human infection. In 
a meta-analysis study with data from 47 countries, the pooled global seroprevalence in swine populations was 19\%, with Europe $(13 \% ; 10-15 \%)$ presenting the lowest and Africa $(25 \% ; 17-34 \%)$ and North America $(25 \% ; 19-33 \%)$ the highest seroprevalence [7]. This high prevalence indicates that pigs are an important source of T. gondii worldwide, while the consumption of pork contaminated with tissue cysts has a huge impact on the transmission to humans [8].

Recently, serological studies have reported the occurrence of $N$. caninum in breeding pigs worldwide. The first N. caninum natural infection was evidenced in Germany in 2004 with only one seropositive pig, western blot confirmed, out of the 2041 animals tested [9]. Most studies refer to the different states of Brazil with seroprevalence presenting an ascending trend over the years from 3.1\% in 2010 [10] and 3.2\% in 2014 [11], to 13.49\% in 2019 [12]. In addition, a seroprevalence of $1.9 \%$ has been reported in 2019 for the first time in pigs in China, with a range of $0.3-4.6 \%$ in the different regions [13], while in the Czech Republic, 3\% of swine were seropositive, with $1.5 \%$ presenting antibodies against both T. gondii and N. caninum [14]. Referring to wildlife, $15.8 \%$ of feral swine populations in the United States were found seropositive against N. caninum [15]. To date, there is a paucity of data referring to swine exposure to N. caninum in Greece.

In Greece, the seroprevalence of $N$. caninum varies among different species. In dogs the seroprevalence was 7.63\% [16], in sheep 2.5-16.8\% [17,18], and in goats $6.9 \%$ [18], while in cattle population, the highest seroprevalence of $20.89-21.03 \%$ has been reported $[19,20]$. In wild animals, the seroprevalence seems to be low, with $1.1 \%$ in wild boars [21] and $0.95 \%$ in hares [22]. Moreover, specific antibodies against T. gondii were detected in different studies in Greece, with seroprevalence varying from $24.1-37 \%$ in humans [23], 48.6-56.3\% in sheep [17,18,24], 30.7-61.3\% in goats [18,24], 8.13\% in cows [20], 4.3\% in swine [25], and $1.8 \%$ in horses [26]. Regarding wildlife, the seroprevalence was $5.7 \%$ in brown hares [22] and $5.2 \%$ in the wild boar population [21].

Immunocompromised hosts are more susceptible to develop severe infection with both opportunistic pathogens T. gondii and N. caninum, while immunocompetent individuals remain mostly asymptomatic $[27,28]$. Polymyositis and myocarditis as a result of T. gondii infection has been described in immunocompetent humans [29-31] and dogs [32], with elevated serum values of aspartate aminotransferase (AST) and creatine kinase (CK). Referring to cats, the definitive host of the parasite, chronic and diffuse inflammatory myopathy associated with elevated CK activity and a history of intermittent lameness has been reported in a seropositive against $T$. gondii adult cats [33]. Cardiac and skeletal muscle involvement has been observed in aborted fetuses or congenitally infected young pigs [34]. Moreover, among the histopathological findings in piglets with clinical toxoplasmosis were the granulomatous myositis of skeletal muscles and necrosis of myocardial cells [35].

Clinical signs like apathy and hypothermia, as well as hematological and biochemical alterations including leukocytosis due to lymphocytosis and increased serum levels of AST and normal gamma glutamyl-transferase (GGT) have been recently reported in an experimental study in sows [36]. This was the first study evaluating the clinical signs and laboratory findings of Neosporosis in swine. However, the effects of N. caninum natural infection on the neuromuscular system in this species remains unclear.

The aims of this study were (a) to detect the presence of antibodies against T. gondii and/or N. caninum in pigs, (b) to identify differences in seropositivity against $T$. gondii and/or $N$. caninum between pigs vaccinated and unvaccinated against porcine circovirus 2 (PCV2), and c) to identify differences in muscle enzyme activity between seropositive and seronegative to T. gondii and/or N. caninum pigs.

\section{Materials and Methods}

\subsection{Ethical Approval}

All procedures were done according to the ethical standards in the Helsinki Declaration of 1975, as revised in 2000, as well as the national law and after receiving approval (Animal Use Ethics Committee of Veterinary Faculty University of Thessaly approval 
code: 65/26-02-2019 and approval date: February 2019) from our Institutional Animal Use Ethics Committee.

\subsection{Inclusion Criteria}

\subsubsection{Farms}

A total of 31 pig farms on the Greek mainland were included in the study (Table 1). The selected 31 farms had totally a population of around 11,500 sows, which represents approximately $20 \%$ of the entire capacity of Greek swine production. Moreover, sampling was performed after receiving the farmer's informed consent, followed by filling in a questionnaire on the herd vaccination scheme. Inclusion criteria of farms were as follows:

- Minimum capacity of 50 sows.

- Operation type of exclusive farrow-to-finish farms.

- Vaccination of gilts/sows against Aujeszky's disease virus, parvovirus, atrophic rhinitis, erysipelas, Porcine Reproductive and Respiratory Virus (PRRSV), Escherichia coli, and Clostridium infections. Vaccination of weaners against Mycoplasma hyopneumoniae.

- Regular control of endo/ectoparasites by administration of ivermectin in sows.

- Single housing systems of sows with farrowing crate, including cast iron slat and solid plastic slat.

- Implementation of environmental conditions and stocking density in compliance with swine welfare requirements (Council Directive 2008/120/EC of 18 December 2008).

- Implementation of good biosecurity practices to reduce the likelihood of disease introduction and/or spread.

- Balanced diet (essential amino acids, minerals, and vitamins) according to National Research Council [37].

- Regular use of toxin binders in the feed of sows during gestation and lactation period and in the feed of weaning pigs.

Table 1. Number of blood samples collected per farm of different farm size.

\begin{tabular}{ccc}
\hline Farm Size $^{\mathbf{1}}$ & Farms & Blood Samples \\
\hline $50-100$ & 6 & 30 \\
$101-250$ & 10 & 100 \\
$251-500$ & 10 & 150 \\
$>500$ & 5 & 100 \\
\hline
\end{tabular}

${ }^{1}$ Number of sows per farm.

\subsubsection{Animals}

Clinically healthy sows of parity 1 and 2 at the 10th day of lactation were selected for the study. Sows with prior injection either for drug administration or blood collection within the last 7 days were excluded.

\subsection{Sampling}

Blood samples were obtained from 380 sows via puncture of the vena jugular externa with a 19-gauge needle into one vacutainer (Venoject, Terumo Europe, Leuven, Belgium) with no anticoagulant for serum retrieval. Samples were transferred to the Diagnostic Laboratory of the Faculty of Veterinary Medicine, School of Health Sciences, University of Thessaly, Greece, and placed in a cooler, with icepacks avoiding direct contact with the tubes. Within $2 \mathrm{~h}$ after collection, blood samples were centrifuged at $300 \times g$ for $10 \mathrm{~min}$. Hemolyzed blood specimens were excluded from the study to avoid any possible interference in the biochemistry results. The serum was recovered, transferred into three plastic vials (Eppendorf Tubes, Eppendorf AG, Hamburg, Germany), and frozen immediately at $-20{ }^{\circ} \mathrm{C}$ pending analysis. One vial was used for the detection of antibodies against $T$. gondii and $N$. caninum and the second one for the biochemical determination of creatine kinase (CK) and aspartate aminotransferase (AST) serum concentrations. The third vial was used 
for PCV2 DNA detection by real-time PCR. The samples selected for PCV2 DNA detection, a method description, and the results are presented in the Supplementary Material.

\subsection{Indirect Immunofluorescence Antibody (IFA) Assay}

For the detection of antibodies against T. gondii and N. caninum, indirect fluorescence antibody test kits using commercially available slides coated with parasite tachyzoites (Fuller Laboratories, Fullerton, CA, USA) and a goat polyclonal fluorescein isothiocyanate (FITC) conjugated anti-pig IgG (Porcine IgG FITC conjugate, VMRD Inc., Pullman, Washington, USA) were used. Nc1 tachyzoites propagated in Vero cells were used for the $N$. caninum slides. After the addition of sera, the slides were incubated for $30 \mathrm{~min}$ at $37^{\circ} \mathrm{C}$. The slides were then washed to remove unreacted serum proteins, and fluorescence labelled anti-porcine IgG (conjugate) was added. After incubation for the same time and at the same conditions, the slides were washed again to remove unreacted conjugate.

For the detection of antibodies against T. gondii and N. caninum, cutoff values of 1:64 and 1:50 were used, respectively. A Nikon Eclipse E-400 fluorescence microscope was used for the observation (objective $\times 40$ ).

\subsection{Biochemical Analysis}

Serum levels of CK and AST were measured by an automated biochemical analyzer (Advia ${ }^{\circledR} 1800$ chemistry analyzer, Siemens Healthineers, Erlangen, Germany) using the commercial diagnostic kits, employing the analytical kinetic methods of $\mathrm{N}$-acetyl cysteine (NAC) activated for CK measurement and the catalytic concentration measurement of AST of the International Federation of Clinical Chemistry.

\subsection{Data Analysis}

A Chi squared test was run to determine the significance of difference in the percentage of seropositivity between vaccinated and unvaccinated pigs, as well as between 1st and 2nd parity sows, using the statistical software MEDCALC 9.2.

The differences in muscle enzyme activity between seropositive and seronegative to $T$. gondii and/or N. caninum pigs were determined in three groups of animals: the (T+) group consisted of animals with IgG against only $T$. gondii, the $(\mathrm{N}+)$ group consisted of animals with IgG against only N. caninum, and the Neg group included seronegative animals for both pathogens. These data were analyzed using the statistical program JASP 14.1. The normality of the data distribution was assessed with the Shapiro-Wilk test. The data for the serum activity of CK and AST were not normally distributed, and Kruskal-Wallis and Mann-Whitney U tests were used to determine the significance of their differences among groups. A value of $p \leq 0.05$ was considered significant in all comparisons.

\section{Results}

Of a total number of 380 blood samples, 16 were excluded from the study due to hemolysis. Out of the 364 swine serologically examined by the IFA assay, $16(4.4 \%)$ animals were $\operatorname{IgG}$ positive against $T$. gondii, $13(3.5 \%)$ animals were $\operatorname{IgG}$ positive against $N$. caninum, and $2(0.5 \%)$ animals were IgG positive against both T. gondii and N. caninum.

Fixed N. caninum and T. gondii tachyzoites indirectly stained by FITC (IFA) appeared sharp bright green colored with a diffuse or peripheral fluorescence pattern, representing a positive IgG antibody reaction (Figure 1). 


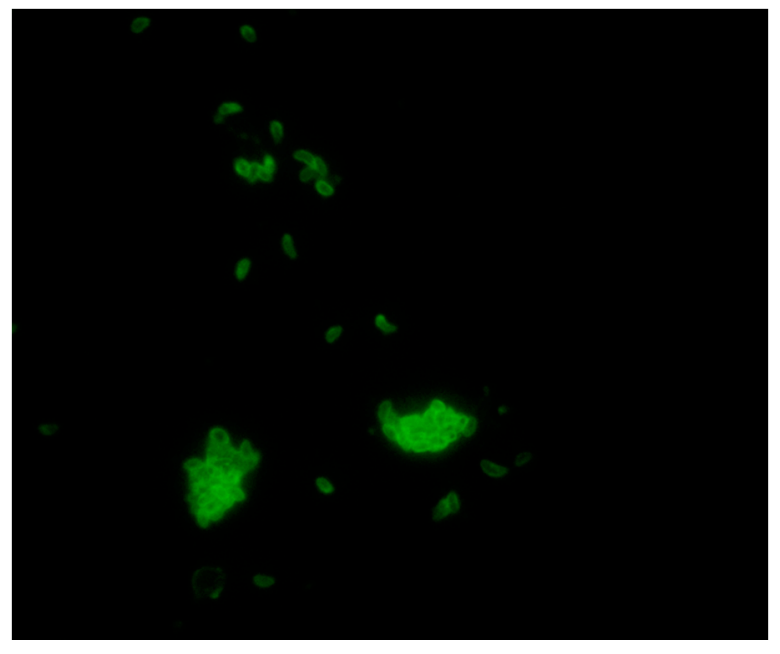

(a)

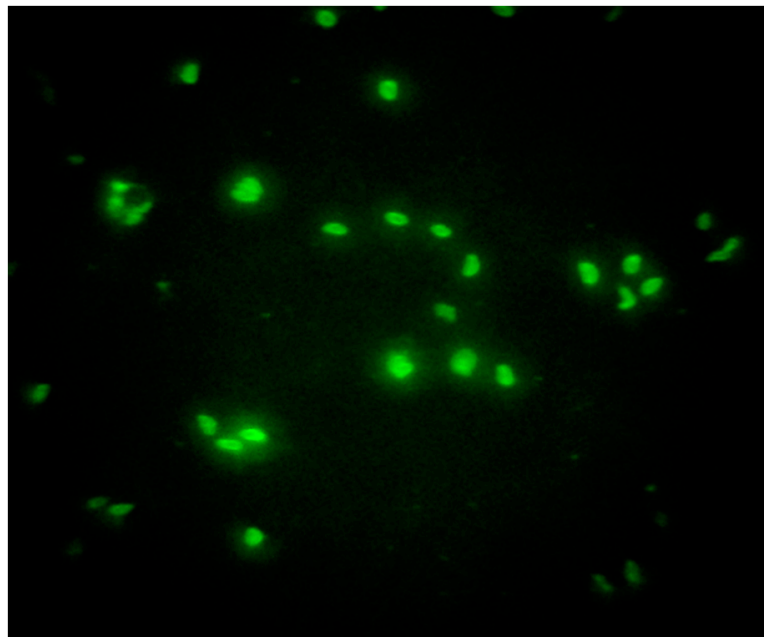

(b)

Figure 1. Image of indirect immunofluorescence antibody (IFA) assay observed by a Nikon Eclipse fluorescence microscope (objective $\times 40$ ). (a) Neospora caninum positive IgG antibody reaction, serum titer 1:100; (b) Toxoplasma gondii positive IgG antibody reaction, serum titer 1:128.

The questionnaire revealed that vaccination against PCV2 was not included in the vaccination scheme of 7 out of the 31 farms sampled in the present study. A total number of 45 blood samples was collected from sows of these farms (Table 2). Out of these 45 blood samples, 3 had already been excluded as they belonged to the 16 samples with hemolysis.

Table 2. Number of porcine circovirus 2 (PCV2) unvaccinated farms to total number of farms and number of blood samples collected from PCV2 unvaccinated farms to total number of blood samples, per farm size.

\begin{tabular}{|c|c|c|}
\hline Farm Size ${ }^{1}$ & $\begin{array}{l}\text { PCV2 Unvaccinated } \\
\text { Farms/Total Farms }\end{array}$ & $\begin{array}{l}\text { Blood Samples from Unvaccinated } \\
\text { Farms/Total Blood Samples }\end{array}$ \\
\hline $50-100$ & $5 / 6$ & $25 / 30$ \\
\hline $101-250$ & $2 / 10$ & $20 / 100$ \\
\hline $251-500$ & $0 / 10$ & $0 / 150$ \\
\hline$>500$ & $0 / 5$ & $0 / 100$ \\
\hline
\end{tabular}

${ }^{1}$ Number of sows per farm.

Statistical analysis revealed significantly higher percentages of seropositivity against T. gondii and/or N. caninum in PCV2 unvaccinated compared to vaccinated pigs (Table 3).

Table 3. Number and percentage of T. gondii and N. caninum seropositive pigs per vaccination status.

\begin{tabular}{ccccc}
\hline \multirow{2}{*}{$\begin{array}{c}\text { PCV2 Vaccination } \\
\text { Status }\end{array}$} & \multicolumn{4}{c}{$\begin{array}{c}\text { Seropositive Pigs } \\
\text { T. gondii (16) N. caninum (13) }\end{array}$} \\
\cline { 2 - 5 } & $\mathbf{N}$ & $\%$ & $\mathbf{N}$ & $\%$ \\
\hline $\begin{array}{c}\text { Vaccinated } \\
(322)\end{array}$ & 9 & $2.79^{1}$ & 1 & $0.31^{1}$ \\
$\begin{array}{c}\text { Unvaccinated } \\
(42)\end{array}$ & 7 & $16.67^{2}$ & 12 & $28.57^{2}$ \\
\hline
\end{tabular}

1,2 Different superscripts in percentages of different rows in the same column denote significant difference, $p<0.0001$.

No significant difference in seropositivity to T. gondii and N. caninum was observed between 1 st and 2 nd parity sows (Table 4 ). 
Table 4. Number and percentage of 1st and 2nd parity sows seropositive against T. gondii and N. caninum.

\begin{tabular}{ccccc}
\hline & \multicolumn{4}{c}{ Seropositive Pigs } \\
Parity & $\mathbf{N}$ & T. gondii (16) N. caninum (13) \\
\cline { 2 - 5 } & 6 & $\%$ & $\mathbf{N}$ & $\%$ \\
\hline $\begin{array}{c}\text { 1st parity } \\
(143) \\
\text { 2nd parity } \\
(221)\end{array}$ & 10 & 4.2 & 7 & 4.9 \\
\hline
\end{tabular}

For the analysis of CK and AST activity, the two animals positive against both T. gondii and $N$. caninum have not been included, as groups were formed by seropositive animals to only one pathogen. Therefore, group $(\mathrm{T}+)$ consisted of 14 animals, group $(\mathrm{N}+)$ consisted of 11 animals, and group (Neg) consisted of 337 animals.

The serum activities of CK and AST were significantly higher in the $\mathrm{T}+$ and $\mathrm{N}+$ groups compared with the Neg group $(p<0.05)$ (Figure 2). However, no significant difference was detected between the $\mathrm{T}+$ and $\mathrm{N}+$ groups $(p>0.05)$.

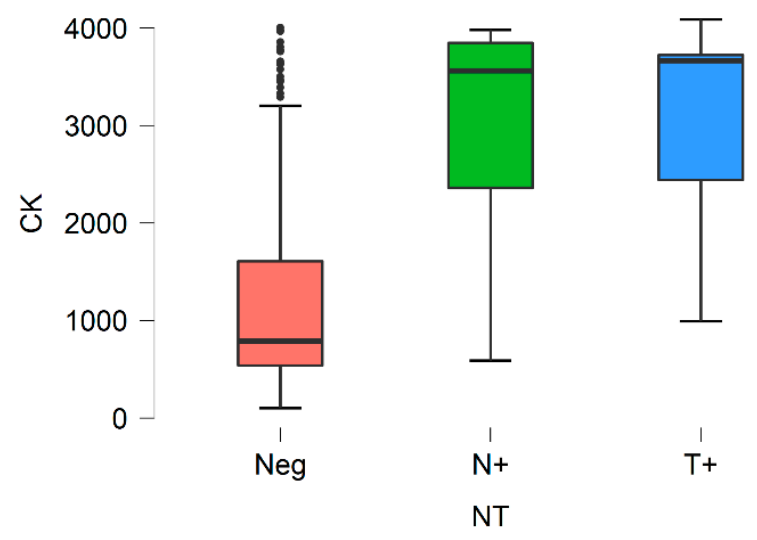

(a)

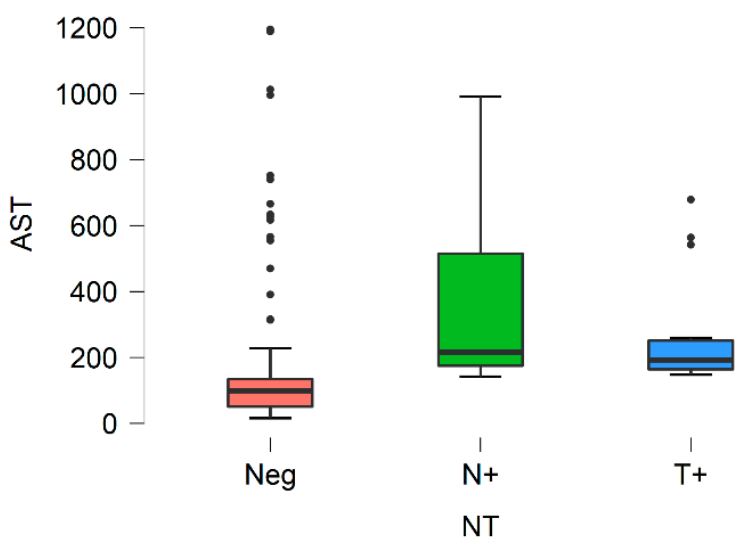

(b)

Figure 2. Dot and box and whisker plots of: (a) creatine kinase (CK) in pigs seronegative to both N. caninum and T. gondii (Neg), seropositive to N. caninum and seronegative to T. gondii $(\mathrm{N}+$ ), and seropositive to T. gondii and seronegative to N. caninum $(\mathrm{T}+)$; (b) aspartate aminotransferase (AST) in pigs seronegative to both N. caninum and T. gondii (Neg), seropositive to $N$. caninum and seronegative to T. gondii $(\mathrm{N}+)$, and seropositive to T. gondii and seronegative to N. caninum $(\mathrm{T}+)$.

A percentage of $71.43 \%$ of the $\mathrm{T}+$ group and $63.64 \%$ of the $\mathrm{N}+$ group presented increased CK activity, while $100 \%$ and $90.91 \%$ of the groups $\mathrm{T}+$ and $\mathrm{N}+$ presented increased AST activity, respectively (Figure 3). Increased serum levels for both enzymes were detected in $71.43 \%$ of the $\mathrm{T}+$ and $54.55 \%$ of the $\mathrm{N}+$ group. Both CK and AST enzyme activities were elevated in the two animals that were seropositive against both $T$. gondii and N. caninum. Our laboratory reference intervals for CK and AST were 50-3521 U/L and AST 16-142 U/L, respectively. 
$\mathrm{T+}$

$\square$ Increased enzyme activity

$\square$ WRI

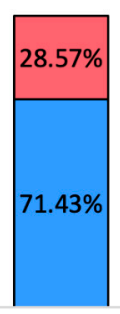

$\mathrm{CK}$

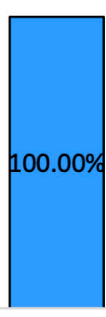

AST

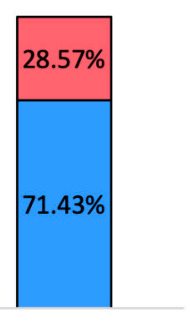

CK-AST

(a)

$\mathrm{N}+$

$\square$ Increased enzyme activity $\quad \square$ WRI

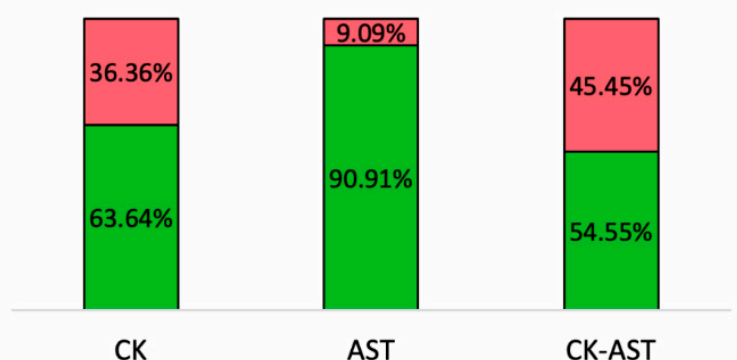

(b)

Figure 3. The percentages of sows with increased creatine kinase (CK), aspartate aminotransferase (AST), and both CK-AST serum activities, as well as the percentages of serum enzyme levels within reference interval (WRI), are presented in percentage stacked columns in (a) seropositive to T. gondii sows $(\mathrm{T}+)$ group; $(\mathbf{b})$ seropositive to N. caninum sows $(\mathrm{N}+)$ group.

\section{Discussion}

This study revealed that $4.4 \%$ and $3.5 \%$ of sows were exposed to T. gondii and $N$. caninum, while coexposure was also evidenced in two (0.5\%) animals. The farms sampled represent a population of around 11,500 sows, $20 \%$ of the total swine population in Greece. The seroprevalence of $4.4 \%$ against $T$. gondii is in accordance, and actually very close to, the previous reporting a seroprevalence of $4.3 \%$ in swine in Greece [25]. T. gondii seroprevalence in Greece is among the lowest in Europe, compared to other European countries-Serbia, Italy, Switzerland, and Romania having the highest percentage of $23-25 \%$ - and compared worldwide, as the pooled prevalence in Europe is $15 \%$, while in Asia it is 21\%, in Africa 25\%, and in South and North America 23\% and 25\%, respectively [7].

Regarding N. caninum, a seroprevalence of $3.5 \%$ was detected in the present study, and this is, to the authors' best knowledge, the first report on swine exposure to N. caninum in Greece. Although antibodies against N. caninum have already been detected in Greece, with the highest seroprevalence reported in cattle $(20.89-21.03 \%)[19,20]$, the seroprevalence in swine seems to be lower than in dogs $(7.63 \%)$ [16], sheep $(2.5-16.8 \%)[17,18]$, and goats (6.9\%) [18] but higher than the seroprevalence in wild boars (1.1\%) [21] and hares $(0.95 \%)$ [22]. At a global level, the seroprevalence of 3.5\% found in Greece is in accordance with the seroprevalences of 3.1-3.2\% in Brazil [10,11], 0.3-4.9\% in China [13], and 3\% in Czech Republic [14] but lower than that of $13.49 \%$ in Brazil in 2019 and $15.8 \%$ in feral swine in the United States [15]. Regarding the percentage of $0.5 \%$ of coexposure to T. gondii and N. caninum, a similar percentage of $1.5 \%$ of coexposure was detected in the Czech Republic [14].

Until the first indication of natural N. caninum infection in swine in 2004, most information about neosporosis in this species came from experimental studies. In swine experimentally inoculated with $N$. caninum tachyzoites, the gilts seroconverted (IgG) on the 5th-7th day after Nc1 strain inoculation with the highest IgG titers at the 14th-28th days, which remained stable positive during at least the gestation period and, in total, 130 days post inoculation [36]. Similarly, when sows are inoculated with $T$. gondii oocysts, they seroconverted (IgG) about 2-3 weeks post inoculation and remained seropositive for at least 38 weeks [38]. However, it should be noted that in both studies, IgG antibodies could remain even longer, as a considerable drop in their concentration was not evidenced in the last sampling. Therefore, the results of the present study are indicative of exposure to both pathogens, while the time of infection remains unknown. In the present study, sows on the 10th day of lactation were sampled; thus, infection could have occurred at any time but at 
least 1-3 weeks prior to sampling, given the time post infection needed for IgG antibodies to be detectable in blood [36,38]. As for any serological test, our results must be interpreted in the light of the pathogenesis of these two protozoans, specifically the timing of antibody appearance in blood. Moreover, apart from the analytical sensitivity and specificity of the IFA assay, the subjectivity and potential interobserver variation of microscopy employed need to be considered. However, samples were evaluated by experienced personnel in the present study, and methods were standardized in our previous studies [21,25]. Finally, the IFA assay is a simple and safe alternative method to the gold standard serological dye test for T. gondii antibody detection in humans according to OIE [39].

It is noteworthy that seropositivity to $N$. caninum has been significantly associated with concurrent seropositivity to T. gondii in HIV-positive humans, since immunocompromised patients are vulnerable to infection with opportunistic pathogens, such as $N$. caninum and T. gondii [28]. The presence of antibodies against $N$. caninum has been evidenced in HIV-infected patients with a high seroprevalence of about 38\% [28], attributed mainly to the disturbed mucosal immune barrier of the gastrointestinal tract, due to mucosal CD4+ T lymphocyte depletion and functional impairment [40]. These high seropositivity rates to $N$. caninum raise concerns about the role of dogs as companion animals and definitive hosts of the parasite and the effect of N. caninum infection in immunocompromised individuals. Relatedly, a concomitant infection with immunosuppressive viruses such as bovine viral diarrhea virus has been evidenced in cattle, contributing to the severity of $N$. caninum infection [41,42].

Regarding the swine immunization status, seropositivity to T. gondii and/or N. caninum was significantly higher in unvaccinated pigs compared to pigs vaccinated against PCV2. PCV2 targets the immune system, mainly the monocytes-macrophages cell line of lymphoid tissue and lungs, with immunopathological and immunosuppressive effects [43]. However, the mechanisms involved in its pathogenesis are not clearly known. One immunosuppressive mechanism employed by the PCV2, is the inhibition of antigen presentation by the dendritic cells and subsequent activation of T-cells, mediated by endothelial IL-8, the expression of which is increased after PCV2 infection of the vascular epithelial cells. Specifically, IL-8 reduces the adhesion and migration of dendritic cells resulting in maturation impairment, with the immature cells exhibiting a low antigen presentation ability [44]. In the present study, although seropositivity was reversely associated with PCV2 vaccination, this association needs to further be exploited since PCV2 disease was not diagnosed, but it is more likely to occur in unvaccinated rather than in vaccinated pigs. The presence of PCV2 viral DNA in unvaccinated pigs (Supplementary Material) is an additional clue supporting the potential implication of PCV2, considering its abovementioned pathogenesis as an immunosuppressive factor, which, however, needs to be confirmed. Moreover, the higher seropositivity to T. gondii and N. caninum in non-PCV2-vaccinated pigs could reflect poor farm management and thus increased exposure to pathogens, including T. gondii and N. caninum.

Infection with $T$. gondii or $N$. caninum may go unnoticed with a high rate of asymptomatic carriers or may cause a variety of clinical signs depending on the host's immune status [3,45]. Muscle tropism and persistence of the parasite's bradyzoite encysted stage may occasionally result in chronic infection, which has been reported to cause a nonresolving myositis with extensive muscle damage due to the persistent accumulation of proinflammatory macrophages [46]. In the present study, CK and AST serum activities were significantly higher in seropositive to T. gondii or N. caninum sows, compared to seronegative ones for both pathogens. Concurrent increased serum levels of CK and AST were evidenced in $71.43 \%$ of the $\mathrm{T}+$ and $54.55 \%$ of the $\mathrm{N}+$ group, as well as in the two sows found seropositive to both T. gondii and N. caninum. Increased serum activities for CK and AST were detected in $71.43 \%$ and $100 \%$ of sows in group T+ and in $63.64 \%$ and $90.91 \%$ of sows in group $\mathrm{N}+$.

The measurement of the serum enzyme activity of specific enzyme markers of muscle stress or injury, such as CK and AST, is critical for the evaluation of neuromuscular disor- 
ders. CK and AST are cytoplasmic and mitochondrial enzymes that leak into bloodstream as a result of injury or loss of cell membrane integrity. CK is expressed in high concentrations in the skeletal muscles, followed by the myocardial muscles, brain, and intestine, while AST is expressed in several tissues and in erythrocytes, with the highest levels in hepatocytes, myocardial, and skeletal muscle cells [47]. Since AST is widely found in many tissues, increased values are a nonspecific indicator for muscle injury and could be either a result of liver damage or hemolysis [48]. However, the possibility of hemolysis interference in the present study is limited, as all hemolyzed specimens were excluded. Although liver implication cannot be excluded, muscle, more than liver, damage seems to be more likely, since elevations in serum AST activity were interpreted along with concurrent elevations in CK activity. Serum AST half-life is approximately $18 \mathrm{~h} \mathrm{[47]} \mathrm{and} \mathrm{longer} \mathrm{than} \mathrm{serum} \mathrm{CK}$ half-life, which is short and approximately $5.2 \mathrm{~h}$ in pigs $[47,49]$. This difference in enzyme half-lives is reflected in the number of animals with elevated muscle activity; CK has a shorter half-life and therefore an elevation in its activity is easier to miss, depending on the time elapsed between sampling and muscle injury.

Increased serum levels of muscle enzymes have been detected after extensive muscular activity in humans [50], dogs [51], and pigs [52], and in pathological conditions of muscle injury like myositis, rhabdomyolysis [53], muscular trauma, muscular dystrophy [54], and acute myocardial injury. There are several references about substance administration and increased muscle enzyme levels due to muscle trauma [55]; however, all animals subjected to injections either for drug administration or blood collection within the last 7 days were excluded from the study. Specifically, in pigs, muscle damage, reflected by elevated serum muscle enzyme activities, has been described in several pathological conditions. Myofiber degeneration and necrosis has been reported in mulberry heart disease and muscular dystrophy, which both have been associated with selenium and vitamin E deficiency [56,57]. However, in the present study, the administration of a balanced diet was within the inclusion criteria and the occurrence of such pathological conditions was rather unlikely. The same holds true for iron, gossypol, or ionophore toxicosis as causes of muscle disease that have been excluded in the farm selection process.

Except for nutritional causes and toxicoses, secondary causes, such as infectious agents and porcine stress syndrome (PSS), can lead to myocardial or skeletal muscle cells degeneration and necrosis [57]. PSS has been associated with an autosomal recessive gene, with the genetic predisposed animals being susceptible and presenting exertional stress under natural conditions and suddenly dying [58]. In an experimental study in stress-susceptible pigs, severe myocardial and skeletal muscle necrosis with a pronounced CK elevation were evidenced after exposure to halothane [59], a stimulant used to test PSS predisposition [60]. In the present study, sampling was performed with the minimal stress induction in sows, and all procedures were done to promote the animals' welfare. However, although stress was minimized as much as possible, it cannot be totally excluded as a partial or overall cause for the increased muscle enzyme levels.

As PCV2 is associated with multisystemic disease, muscle involvement has also been described, including the presence of granulomatous necrotizing myositis of skeletal muscles accompanied by locomotor clinical signs [61] and acute necrotizing or chronic fibrosing myocarditis [62]; however, both studies refer to growing and fattening pigs, with the infected pigs aged 28-120 days old. Elevated muscle enzyme activities could have been a result of trichinellosis. Trichinella spiralis causes structural remodeling and biochemical disturbances in muscle tissue by the larvae invasion in myocytes, growth, and encapsulation [63]. However, trichinellosis in Greece is highly unlikely in commercial farms, since an active surveillance program is carried out in all European countries, according to EC regulation 1375/2015 [64], so cases of trichinellosis are sporadically observed only in wild or free-range pigs [65].

Regarding the only previous reference to AST and neosporosis in pigs, an increase was also observed in accordance with the present study [36]. However, in that case, AST was used along with GGT testing to identify liver and not muscle damage, with the 
latter enzyme remaining within the reference interval [36], suggestive of muscle, and not liver, involvement.

The presence of antibodies against $T$. gondii and N. caninum raises concerns about the source and the factors contributing to the infection or possible reactivation of a latent infection, as indicated by the laboratory-evidenced muscle damage. Among these factors, host immunity status, as indicated in the present study by the highest seropositivity rates for both pathogens in sows unvaccinated against PCV2, seems to play a critical role and needs further elucidation. Moreover, epidemiological studies should be regularly repeated to ascertain the epidemiological status and to define the preventative measures. While $T$. gondii infection, as a global opportunistic zoonotic parasite, has been broadly studied in humans and animals, the effect of $N$. caninum infection in humans remains unclear. Thus, the elucidation of the pathogenicity of N. caninum swine infection in further documented immunocompromised and immunocompetent pigs will also serve as a model for human disease.

\section{Conclusions}

In the present study, evidence of the exposure of pigs to T. gondii and, for the first time, N. caninum in Greece is provided. Moreover, the presence of antibodies was associated with increased muscle enzyme activity, suggestive of muscle injury, especially in sows with potentially altered or suppressed immunity, either due to pregnancy or to lack of vaccination against the immunosuppressive virus PCV2. Although the importance of seroprevalence studies on T. gondii is well documented in pigs due to its zoonotic potential, the evidence of $N$. caninum exposure or infection in humans highlights the necessity of similar studies for N. caninum in pigs, at least as an animal model of N. caninum pathogenesis, especially in immunocompromised animals.

Supplementary Materials: The following are available online at https:/ /www.mdpi.com/article/ 10.3390 /microorganisms $9051097 /$ s1.

Author Contributions: Conceptualization, L.V.A. and A.D.; methodology, V.G.P.; software, V.M.S.; validation, L.V.A. and V.G.P.; formal analysis, V.M.S.; investigation, E.G.K.; resources, L.V.A.; data curation, A.D.; writing—original draft preparation, E.G.K. and V.M.S.; writing—review and editing, L.V.A., V.G.P., V.M.S., E.G.K., and A.D.; visualization, E.G.K. and V.M.S.; supervision, L.V.A. and A.D.; project administration, A.D.; funding acquisition, L.V.A., V.G.P., and A.D. All authors have read and agreed to the published version of the manuscript.

Funding: This research received no external funding.

Data Availability Statement: The data presented in this study are available on request from the corresponding author. The data are not publicly available due to further processing for other studies.

Conflicts of Interest: The authors declare no conflict of interest.

\section{References}

1. Berman, J.J. Chapter 19-Apicomplexa. In Taxonomic Guide to Infectious Diseases; Berman, J.J., Ed.; Academic Press: Boston, MA, USA, 2012; pp. 103-109. [CrossRef]

2. Khan, A.; Shaik, J.S.; Sikorski, P.; Dubey, J.P.; Grigg, M.E. Neosporosis: An Overview of Its Molecular Epidemiology and Pathogenesis. Engineering 2020, 6, 10-19. [CrossRef]

3. Hill, D.; Dubey, J.P. Toxoplasma gondii: Transmission, diagnosis and prevention. Clin. Microbiol. Infect. 2002, 8, 634-640. [CrossRef]

4. Flegr, J.; Prandota, J.; Sovickova, M.; Israili, Z.H. Toxoplasmosis-A global threat. Correlation of latent toxoplasmosis with specific disease burden in a set of 88 countries. PLoS ONE 2014, 9, e90203. [CrossRef]

5. WHO. Toxoplasmosis Fact Sheet. Available online: https://www.euro.who.int/_data/assets/pdf_file/0011/294599/FactsheetToxoplasmosis-en.pdf?ua=1 (accessed on 19 February 2021).

6. Duarte, P.O.; Oshiro, L.M.; Zimmermann, N.P.; Csordas, B.G.; Dourado, D.M.; Barros, J.C.; Andreotti, R. Serological and molecular detection of Neospora caninum and Toxoplasma gondii in human umbilical cord blood and placental tissue samples. Sci. Rep. 2020, 10, 9043. [CrossRef] 
7. Foroutan, M.; Fakhri, Y.; Riahi, S.M.; Ebrahimpour, S.; Namroodi, S.; Taghipour, A.; Spotin, A.; Gamble, H.R.; Rostami, A. The global seroprevalence of Toxoplasma gondii in pigs: A systematic review and meta-analysis. Vet. Parasitol. 2019, $269,42-52$. [CrossRef]

8. Dubey, J.P.; Gamble, H.R.; Hill, D.; Sreekumar, C.; Romand, S.; Thulliez, P. High Prevalence Of Viable Toxoplasma Gondii Infection In Market Weight Pigs From A Farm In Massachusetts. J. Parasitol. 2002, 88, 1234-1238. [CrossRef]

9. Damriyasa, I.M.; Bauer, C.; Edelhofer, R.; Failing, K.; Lind, P.; Petersen, E.; Schares, G.; Tenter, A.M.; Volmer, R.; Zahner, H. Cross-sectional survey in pig breeding farms in Hesse, Germany: Seroprevalence and risk factors of infections with Toxoplasma gondii, Sarcocystis spp. and Neospora caninum in sows. Vet. Parasitol. 2004, 126, 271-286. [CrossRef] [PubMed]

10. Azevedo, S.S.; Pena, H.F.; Alves, C.J.; Guimarães Filho, A.A.; Oliveira, R.M.; Maksimov, P.; Schares, G.; Gennari, S.M. Prevalence of anti-Toxoplasma gondii and anti-Neospora caninum antibodies in swine from Northeastern Brazil. Rev. Bras. Parasitol. Vet. 2010, 19, 80-84. [CrossRef]

11. Feitosa, T.F.; Vilela, V.L.; de Melo, L.R.; de Almeida Neto, J.L.; Souto, D.V.; de Morais, D.F.; Athayde, A.C.; Azevedo, S.S.; Pena, H.F. Toxoplasma gondii and Neospora caninum in slaughtered pigs from Northeast, Brazil. Vet. Parasitol. 2014, 202, 305-309. [CrossRef]

12. Minetto, M.K.; Witter, R.; Oliveira, A.C.S.; Minetto, J.A.; Barros, M.L.; Aguiar, D.M.; Pacheco, R.C. Antibodies anti-Toxoplasma gondii and anti-Neospora caninum in backyard pigs from the state of Mato Grosso, Brazil. Rev. Bras. Parasitol. Vet. 2019, 28, 403-409. [CrossRef]

13. Gui, B.Z.; Lv, Q.Y.; Ge, M.; Li, R.C.; Zhu, X.Q.; Liu, G.H. First report of Neospora caninum infection in pigs in China. Transbound. Emerg. Dis. 2020, 67, 29-32. [CrossRef]

14. Bártová, E.; Sedlák, K. Seroprevalence of Toxoplasma gondii and Neospora caninum in slaughtered pigs in the Czech Republic. Parasitology 2011, 138, 1369-1371. [CrossRef]

15. Bevins, S.; Blizzard, E.; Bazan, L.; Whitley, P. Neospora caninum exposure in overlapping populations of coyotes (Canis latrans) and feral swine (Sus scrofa). J. Wildl. Dis. 2013, 49, 1028-1032. [CrossRef] [PubMed]

16. Lefkaditis, M.; Spanoudis, K.; Tsakiroglou, M.; Panorias, A.; Sossidou, A. Seroprevalence of Neospora caninum infection in stray dogs in Chalkidiki, Northern Greece. J. Hell. Vet. Med Soc. 2021, 71, 2511-2514. [CrossRef]

17. Kouam, M.; Kantzoura, V.; Cabezón, O.; Nogareda, C.; Almería, S.; Theodoropoulos, G. Comparative cross-sectional study of Neospora caninum and Toxoplasma gondii: Seroprevalence in sheep of Greece and North-Eastern Spain. Sustain. Dev. Cult. Tradit. J. 2019, 1-7. [CrossRef]

18. Diakou, A.; Papadopoulos, E.; Panousis, N.; Charilaos, K.; Giadinis, N. Toxoplasma gondii and Neospora caninum seroprevalence in dairy sheep and goats mixed stock farming. Vet. Parasitol. 2013, 198. [CrossRef]

19. Lefkaditis, M.; Mpairamoglou, R.; Sossidou, A.; Spanoudis, K.; Tsakiroglou, M. Neospora caninum, A potential cause of reproductive failure in dairy cows from Northern Greece. Vet. Parasitol. Reg. Stud. Rep. 2020, 19, 100365. [CrossRef]

20. Lefkaditis, M.; Evagelopoulou, G.; Sossidou, A.; Spanoudis, K. Neosporosis and toxoplasmosis are two prevalent and important protozoses in dairy cows in small farms from Thessaly, Central Greece. J. Hell. Vet. Med Soc. 2020, 71, 2357-2362. [CrossRef]

21. Touloudi, A.; Valiakos, G.; Athanasiou, L.V.; Birtsas, P.; Giannakopoulos, A.; Papaspyropoulos, K.; Kalaitzis, C.; Sokos, C.; Tsokana, C.N.; Spyrou, V.; et al. A serosurvey for selected pathogens in Greek European wild boar. Vet. Rec. Open 2015, 2, e000077. [CrossRef]

22. Tsokana, C.N.; Sokos, C.; Giannakopoulos, A.; Birtsas, P.; Athanasiou, L.V.; Valiakos, G.; Sofia, M.; Chatzopoulos, D.C.; Kantere, M.; Spyrou, V.; et al. Serological and molecular investigation of selected parasitic pathogens in European brown hare (Lepus europaeus) in Greece: Inferring the ecological niche of Toxoplasma gondii and Leishmania infantum in hares. Parasitol. Res. 2019, 118, 2715-2721. [CrossRef]

23. Diza, E.; Frantzidou, F.; Souliou, E.; Arvanitidou, M.; Gioula, G.; Antoniadis, A. Seroprevalence of Toxoplasma gondii in northern Greece during the last 20 years. Clin. Microbiol. Infect. Off. Publ. Eur. Soc. Clin. Microbiol. Infect. Dis. 2005, 11, 719-723. [CrossRef]

24. Tzanidakis, N.; Maksimov, P.; Conraths, F.; Kiossis, E.; Brozos, C.; Sotiraki, S.; Schares, G. Toxoplasma gondii in sheep and goats: Seroprevalence and potential risk factors under dairy husbandry practices. Vet. Parasitol. 2012, 190. [CrossRef]

25. Papatsiros, V.G.; Athanasiou, L.V.; Stougiou, D.; Papadopoulos, E.; Maragkakis, G.G.; Katsoulos, P.D.; Lefkaditis, M.; Kantas, D.; Tzika, E.D.; Tassis, P.D.; et al. Cross-Sectional Serosurvey and Risk Factors Associated with the Presence of Toxoplasma gondii Antibodies in Pigs in Greece. Vector Borne Zoonotic Dis. 2016, 16, 48-53. [CrossRef] [PubMed]

26. Kouam, M.K.; Diakou, A.; Kanzoura, V.; Papadopoulos, E.; Gajadhar, A.A.; Theodoropoulos, G. A seroepidemiological study of exposure to Toxoplasma, Leishmania, Echinococcus and Trichinella in equids in Greece and analysis of risk factors. Vet. Parasitol. 2010, 170, 170-175. [CrossRef]

27. Webster, J.P.; Dubey, J.P. Toxoplasmosis of Animals and Humans. Parasites Vectors 2010, 3, 112. [CrossRef]

28. Lobato, J.; Silva, D.A.O.; Mineo, T.W.P.; Amaral, J.D.H.F.; Segundo, G.R.S.; Costa-Cruz, J.M.; Ferreira, M.S.; Borges, A.S.; Mineo, J.R. Detection of immunoglobulin G antibodies to Neospora caninum in humans: High seropositivity rates in patients who are infected by human immunodeficiency virus or have neurological disorders. Clin. Vaccine Immunol. 2006, 13, 84-89. [CrossRef] [PubMed]

29. Paspalaki, P.K.; Mihailidou, E.P.; Bitsori, M.; Tsagkaraki, D.; Mantzouranis, E. Polyomyositis and myocarditis associated with acquired toxoplasmosis in an immunocompetent girl. BMC Musculoskelet. Disord. 2001, 2, 8. [CrossRef] 
30. Hassene, A.; Vital, A.; Anghel, A.; Guez, S.; Series, C. Acute acquired toxoplasmosis presenting as polymyositis and chorioretinitis in immunocompetent patient. Jt. Bone Spine 2008, 75, 603-605. [CrossRef] [PubMed]

31. Cuomo, G.; D'Abrosca, V.; Rizzo, V.; Nardiello, S.; La Montagna, G.; Gaeta, G.B.; Valentini, G. Severe polymyositis due to Toxoplasma gondii in an adult immunocompetent patient: A case report and review of the literature. Infection 2013, 41, 859-862. [CrossRef] [PubMed]

32. Evans, J.; Levesque, D.; Shelton, G.D. Canine Inflammatory Myopathies: A Clinicopathologic Review of 200 Cases. J. Vet. Intern. Med. 2004, 18, 679-691. [CrossRef] [PubMed]

33. Butts, D.R.; Langley-Hobbs, S.J. Lameness, generalised myopathy and myalgia in an adult cat with toxoplasmosis. J. Feline Med. Surg. Open Rep. 2020, 6, 2055116920909668. [CrossRef]

34. Dubey, J.P.; Schlafer, D.H.; Urban, J.F., Jr.; Lindsay, D.S. Lesions in fetal pigs with transplacentally-induced toxoplasmosis. Vet. Pathol. 1990, 27, 411-418. [CrossRef]

35. Dubey, J.P. A review of toxoplasmosis in pigs. Vet. Parasitol. 1986, 19, 181-223. [CrossRef]

36. Snak, A.; Henrique, S.M.; Sebolt, A.P.R.; Cristani, J.; Sato, M.E.; Miletti, L.C.; de Moura, A.B. Experimental infection of tachyzoites of the NC1 strain of Neosporacaninum in female swine. Parasitol. Res. 2021, 120, 1049-1057. [CrossRef] [PubMed]

37. National-Research-Council. Nutrient Requirements of Swine, 11th ed.; The National Academies Press: Washington, DC, USA, 2012. [CrossRef]

38. Basso, W.; Grimm, F.; Ruetten, M.; Djokic, V.; Blaga, R.; Sidler, X.; Deplazes, P. Experimental Toxoplasma gondii infections in pigs: Humoral immune response, estimation of specific IgG avidity and the challenges of reproducing vertical transmission in sows. Vet. Parasitol. 2017, 236, 76-85. [CrossRef]

39. OIE. Chapter 2.9.10.-Toxoplasmosis. Available online: https://www.oie.int/fileadmin/Home/eng/Health_standards/tahm/ maj2011/2.09.10_TOXO.pdf (accessed on 15 May 2021).

40. Jamieson, D.J.; Theiler, R.N.; Rasmussen, S.A. Emerging infections and pregnancy. Emerg. Infect. Dis. 2006, 12, 1638-1643. [CrossRef] [PubMed]

41. Bjorkman, C.; Alenius, S.; Manuelsson, U.; Uggla, A. Neospora caninum and Bovine Virus Diarrhoea Virus Infections in Swedish Dairy Cows in Relation to Abortion. Vet. J. 2000, 159, 201-206. [CrossRef] [PubMed]

42. Alves, M.E.M.; Fernandes, F.; Monteiro, F.L.; Braunig, P.; Cargnelutti, J.F.; Flores, E.F.; Weiblen, R.; Vogel, F.S. Co-infection by Neopora caninum and bovine viral diarrhea virus in cattle from Rio Grande do Sul, Brazil, destined to exportation. Pesq. Vet. Bras. 2020. [CrossRef]

43. Segalés, J.; Domingo, M.; Chianini, F.; Majó, N.; Domínguez, J.; Darwich, L.; Mateu, E. Immunosuppression in postweaning multisystemic wasting syndrome affected pigs. Vet. Microbiol. 2004, 98, 151-158. [CrossRef]

44. Liu, S.; Li, Q.; Qiao, J.; Wang, J.; Cui, D.; Gu, K.; Zhou, S.; Li, H. Endothelial IL-8 induced by porcine circovirus type 2 affects dendritic cell maturation and antigen-presenting function. Virol. J. 2019, 16, 154. [CrossRef]

45. Dubey, J.P.; Lappin, M.R. Toxoplasmosis and neosporosis. In Infectious Diseases of Dogs and Cats; Greene, C.E., Ed.; SaundersElsevier: St. Louis, MO, USA, 2005; pp. 754-775.

46. Jin, R.M.; Blair, S.J.; Warunek, J.; Heffner, R.R.; Blader, I.J.; Wohlfert, E.A. Regulatory T Cells Promote Myositis and Muscle Damage in Toxoplasma gondii Infection. J. Immunol. 2017, 198, 352-362. [CrossRef] [PubMed]

47. Grindem, C.B.; Neel, J.A.; Escobar, C. Evaluation of Skeletal Muscle Function and Injury. In The Clinical Chemistry of Laboratory Animals, 3rd ed.; Kurtz, D.M., Travlos, G.S., Eds.; Taylor \& Francis: Boca Raton, FL USA, 2018; pp. 475-514.

48. Stockham, S.L.; Scott, M.A. Enzymes. In Fundamentals of Veterinary Clinical Pathology, 2nd ed.; Wiley-Blackwell: Ames, IA, USA, 2008; pp. 640-669.

49. Boyd, J.W. The mechanisms relating to increases in plasma enzymes and isoenzymes in diseases of animals. Vet. Clin. Pathol. 1983, 12, 9-24. [CrossRef] [PubMed]

50. Brancaccio, P.; Maffulli, N.; Buonauro, R.; Limongelli, F.M. Serum enzyme monitoring in sports medicine. Clin. Sports Med. 2008, 27, 1-18. [CrossRef] [PubMed]

51. Lucas, V.; Barrera, R.; Duque, F.J.; Ruiz, P.; Zaragoza, C. Effect of exercise on serum markers of muscle inflammation in Spanish Greyhounds. Am. J. Vet. Res. 2015, 76, 637-643. [CrossRef]

52. Doize, F.; Laporte, R.; DeRoth, L. Effects of exercise on skeletal muscle and serum enzyme activities in pigs. Vet. Res. Commun. 1989, 13, 341-347. [CrossRef]

53. Szumilak, D.; Sułowicz, W.; Walatek, B. Rhabdomyolysis: Clinical features, causes, complications and treatment. Przegl. Lek. 1998, $55,274-279$.

54. Mokuno, K.; Riku, S.; Sugimura, K.; Takahashi, A.; Kato, K.; Osugi, S. Serum creatine kinase isoenzymes in Duchenne muscular dystrophy determined by sensitive enzyme immunoassay methods. Muscle Nerve 1987, 10, 459-463. [CrossRef] [PubMed]

55. Athanasiou, L.V.; Polizopoulou, Z.S.; Papaioannou, N.; Roubies, N.; Bodina, E.S. Effects of injection volume and excipient on muscle enzyme activity and post injection muscle damage. In Proceedings of the congress of the International Society of Animal Clinical Biochemistry, Instabul, Turkey, 1 May 2006; p. 93.

56. Gudmundson, J. The clinicopathological findings of mulberry heart disease in a piglet. Can. Vet. J. 1976, $17,45-47$.

57. Loynachan, A.T. Cardiovascular and Hematopoietic Systems. In Diseases of Swine, 10th ed.; John Wiley \& Sons, Inc.: West Sussex, UK, 2012; pp. 189-198. 
58. Done, S.; Williamson, S.M.; Strugnell, B.W. Porcine Stress Syndrome. In Diseases of Swine, 10th ed.; John Wiley \& Sons, Inc.: West Sussex, UK, 2012; pp. 314-315.

59. Thorén-Tolling, K.; Jönsson, L. Creatine kinase isoenzymes in serum of pigs having myocardial and skeletal muscle necrosis. Can. J. Comp. Med. 1983, 47, 207-216.

60. Webb, A.J.; Jordan, C.H.C. Halothane sensitivity as a field test for stress-susceptibility in the pig. Anim. Sci. 1978, 26, 157-168. [CrossRef]

61. Konradt, G.; Cruz, R.A.S.; Bassuino, D.M.; Bianchi, M.V.; de Andrade, C.P.; da Silva, F.S.; Driemeier, D.; Pavarini, S.P. Granulomatous Necrotizing Myositis in Swine Affected by Porcine Circovirus Disease. Vet. Pathol. 2018, 55, 268-272. [CrossRef]

62. Opriessnig, T.; Janke, B.H.; Halbur, P.G. Cardiovascular lesions in pigs naturally or experimentally infected with porcine circovirus type 2. J. Comp. Pathol. 2006, 134, 105-110. [CrossRef]

63. Wu, Z.; Sofronic-Milosavljevic, L.; Nagano, I.; Takahashi, Y. Trichinella spiralis: Nurse cell formation with emphasis on analogy to muscle cell repair. Parasites Vectors 2008, 1, 27. [CrossRef] [PubMed]

64. Van der Giessen, J.; Deksne, G.; Gómez-Morales, M.A.; Troell, K.; Gomes, J.; Sotiraki, S.; Rozycki, M.; Kucsera, I.; DjurkovićDjaković, O.; Robertson, L.J. Surveillance of foodborne parasitic diseases in Europe in a One Health approach. Parasite Epidemiol. Control 2021, 13, e00205. [CrossRef] [PubMed]

65. Boutsini, S.; Papatsiros, V.G.; Stougiou, D.; Marucci, G.; Liandris, E.; Athanasiou, L.V.; Papadoudis, A.; Karagiozopoulos, E.; Bisias, A.; Pozio, E. Emerging Trichinella britovi infections in free ranging pigs of Greece. Vet. Parasitol. 2014, 199, $278-282$. [CrossRef] [PubMed] 